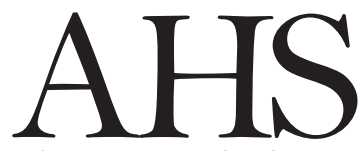

Advances in Horticultural Science

\title{
'Momordica charantia' introducing a new rootstock for grafted cucumber under low-temperature stress
}

\author{
S. Mohammadnia, M. Haghighi ${ }^{(*)}$ \\ Department of Horticulture, College of Agriculture, Isfahan University of \\ Technology, Isfahan, Iran.
}

Key words: Cucurbita maxima, female flower, Karela, photosynthesis, rootstock, yield.

OPEN ACCESS
Abbreviation: $\mathrm{Rma}=$ grafted onto Cucurbita maxima; $\mathrm{Rmo}=$ grafted onto Momordica charantia; $\mathrm{Rn}=$ non-grafted; $\mathrm{Rs}=$ self-grafted; $\mathrm{Tc}=\mathrm{con}$ - trol temperature; $\mathrm{Ts}=$ stress temperature.

(*) Corresponding author: $^{\text {mhaghighi@iut.ac.ir }}$

Citation:

MOHAMMADNIA S., HAGHIGHI M., 2021 'Momordica charantia' introducing a new rootstock for grafted cucumber under lowtemperature stress. - Adv. Hort. Sci., 35(2): 99110

\section{Copyright:}

(C) 2021 Mohammadnia S., Haghighi M. This is an open access, peer reviewed article published by Firenze University Press

(http://www.fupress.net/index.php/ahs/) and distributed under the terms of the Creative Commons Attribution License, which permits unrestricted use, distribution, and reproduction in any medium, provided the original author and source are credited.

Data Availability Statement:

All relevant data are within the paper and its Supporting Information files.

Competing Interests:

The authors declare no competing interests.

Received for publication 3 February 2021 Accepted for publication 12 February 2021
Abstract: Cucumber is a sensitive vegetable to low temperatures. Grafting vegetables on different rootstocks can decrease the harmful effects of environmental stresses, including low-temperature stress. An experiment was performed to evaluate grafting cucumbers on different rootstocks at low temperatures. Cucumber growth and yield and photosynthesis traits were examined. Treatments were the optimum temperature $\left(25 \pm 2^{\circ} \mathrm{C}\right)$, and cold temperature $\left(15 \pm 3^{\circ} \mathrm{C}, \mathrm{Ts}\right)$, and rootstocks, were Momordica charantia (Rmo), Cucurbita maxima (Rma), non-grafted (Rn) and self- grafted (Rs) with 4 replications. Shoot fresh and dry weight, chlorophyll, RWC, transpiration, decreased with temperature stress. The number of female flowers, electrolyte leakage, photosynthesis, stomatal conductance increased with Ts. First fruit emergence per plant, N, P, $\mathrm{K}, \mathrm{Mg}$ concentration decreased with Ts stress. Transpiration, female flower, RWC, and stomata conductance, N, P, K, Ca, and phenol increased in Rma and $\mathrm{Rmo}$. $\mathrm{Mg}$ was at the highest concentration in $\mathrm{Rma}$ and $\mathrm{Na}$ in $\mathrm{Rn}$. All in all, using $\mathrm{Rmo}$ as well as Rma is recommended for rootstock as it causes more reproductive growth.

\section{Introduction}

Recently, the greenhouse culture of plants has widely expanded (Yan et al., 2013). Cucumbers (Cucumis sativus) are commonly grown in the greenhouse. The optimal temperature for aerial growth and roots are about $28-23 / 18-15^{\circ} \mathrm{C}$ (day/night) and $20^{\circ} \mathrm{C}$, respectively (Ikeda and Kawashiro, 2005). Thus, cucumbers are cold-sensitive vegetables. Lowtemperature stress can occur in plastic culture or non-equipped greenhouses, which are very common in Iran. It may also affect field culture cucumbers and spring culture cucumbers. Low temperatures have differ- 
ent deleterious effects on cucumbers, including affecting the nutrient uptake of plants (Pregitzer and King, 2005), and inducing greater $\mathrm{H}_{2} \mathrm{O}_{2}, \mathrm{MDA}$, and soluble sugar content in cucumbers, causing damage to plants and inhibiting plant growth (Qiu-yan et al., 2013).

There are several ways to control low-temperature damage to plants, including controlling root temperatures by warming nutrient solution or soil. Still, these ways require excess energy (Willits and Peet, 1998). Finally, excess chemical nutrient applications for promoting growth can prevent damage to plants, which unfortunately involves environmental risks. Therefore, vegetable grafting can be a proper way to increase plant resistance to environmental stresses in addition to expanding its yield, quality, and growth. Furthermore, if any energy-efficient way is introduced, which can raise the growth rate of plants in greenhouse conditions at lower temperatures, vast amounts of energy and money will be saved. Vegetable grafting has been used to increase plant tolerance under environmental stresses, including high temperatures (Rivero et al., 2003), low temperatures (Rivero et al., 2003), salinity stresses (Estan et al., 2005), drought stresses (Bhatt et al., 2002) and heavy metal stresses (Edelstein et al., 2005).

Fig leaf gourd and bur cucumbers (Sicyos angulatus) are used for increasing resistance against lowtemperature stresses for cucumber rootstocks (Venema et al., 2008). These rootstocks increase plant resistance using different ways. First, low-temperature stresses decrease $\mathrm{Co}_{2}$ assimilation in cucumbers and this reduction is improved by grafting (Zhou et al., 2009). Secondly, a previous study done by Zhou et al. (2007) showed that fig leaf gourd rootstocks enhanced vegetative growth and yield of cucumbers under low-temperature stresses.

There is a hypothesis stating that grafted plant responses to temperature stresses are related to scion species (Venema et al., 2005). Many researchers have shown beneficial effects of vegetable grafting on the growth, fruit yield, and quality of plants. Some of the studies have used different rootstocks for cucumbers under different stresses showing better growth rate for grafted plants under stress conditions compared to non-grafted ones like: heavy metal absorption (Rouphael et al., 2008; Kumar et al., 2015), low soil temperatures (Tachibana, 1982), salinity (Huang et al., 2010), improve $\mathrm{NaCl}$ and $\mathrm{CaCl}_{2}$ tolerance in Cucumber (Colla et al., 2013), Al toxicity in cucumber (Rouphael et al.,
2016).

Different rootstocks were used in normal and stress conditions to improve yield and growth traits like different kinds of squash (Yang et al., 2006), (Massai et al., 2004), (Rouphael et al., 2008), Fig leaf guard (Tachibana, 1982), pumpkins and bottle gourd and P360 (Cucurbita maxima Duch.xCucurbita moschata Duch.) (Colla et al., 2010 and 2013). To the best of our knowledge, few studies have investigated the use of Momordica charantia as a rootstock for cucurbits, or more explicitly grafting, to examine the possibility of cucumber cultivation at low temperatures in the whole growth period. Hence, the goal of the present study was the use of Momordica charantia and Cucurbita maxima as rootstocks and Cucumis sativus var. Davosll, which is a common variety of cucumbers in Iran as a scion under low-temperature stress.

\section{Materials and Methods}

\section{Experimental design and plant preparation}

This experiment was conducted in a plastic greenhouse in the Department of Horticulture Science at the Isfahan University of Technology, Isfahan, Iran. An investigation was arranged as a combined analysis involving data from two locations, simultaneously collected, based on CRD with 4 replications. Treatments were optimum $\left(25 \pm 2^{\circ} \mathrm{C}, \mathrm{Tc}\right)$ and low temperatures $\left(15 \pm 3^{\circ} \mathrm{C}, \mathrm{Ts}\right)$. Cucumbers (Cucumis sativus var. Davosll) were grafted to Momordica charantia (Rmo), Cucurbita maxima (Rma). Non-grafted (Rn) and self-grafted (Rs) consider as a control. Scion seeds had been cultivated 10 days before rootstock seeds in cocopeat: perlite 1:1. Scion plants and rootstocks were cut beneath and above the first true leaves, respectively. Hole-insertion grafting was used and grafted plants were transferred to a recovery greenhouse with high relative humidity. Plants were kept for 2 weeks in recovery conditions and gradually adapted to normal greenhouse conditions. Grafted plants were transferred to $5 \mathrm{~kg}$ pots, including soil. Irrigation was used when the plant needed it. Chemical fertilizer NPK $(20,20,20) 2 \mathrm{mg} /$ pot was applied every 10 days. Plants were conducted to wire above the greenhouse, and there was no use of any pesticide.

\section{Plant growth and fruit properties}

The male and female flower, node numbers, and shoot numbers were counted during the experiment; 
root and internode length was determined with a ruler. The time and node of male and female flower emergence were recorded. Fruit diameter, fruit firmness, and TSS were measured with a caliper (Mitutoyo Corp, Japan), Pentameter (model OSK-I10576), and portable Refractometer (PAL ${ }^{-1}$ Brix, Japan), respectively (Raeisi et al., 2014).

Shoots were excised from the roots using a steel blade and then fresh weights of roots and shoots were measured. All the samples were oven-dried at $70^{\circ} \mathrm{C}$ for 48 hours and the dry weights were estimated. During the experiment and finally 124 days after transplanting, fruits were harvested and washed using tap water and were weighed by an analytical balance.

\section{SPAD value and photosynthesis trait assay}

Chlorophyll content was measured using a chlorophyll meter (SPAD-502 plus, Minolta, Japan). Fv/Fm was measured by chlorophyll fluorescence (OS- 30, USA) after 3 weeks. Photosynthetic properties were determined from the youngest fully-expanded leaf for 3 replications per treatment by Portable photosynthesis systems for gas exchange and chlorophyll fluorescence measurements (LI-COR-6400, USA) from 10:00 to 11:00 AM on a clear day (without clouds). The measurements were conducted with photosynthetically active radiation (PAR) intensity of 1000 $\mu \mathrm{mol} \mathrm{m} \mathrm{m}^{-2} \mathrm{~s}^{-1}$ and $\mathrm{CO}_{2}$ concentration of $350 \mu \mathrm{mol} \cdot \mathrm{mol}$.

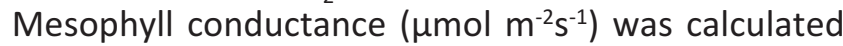
by dividing the photosynthetic rate by the sub-stomatal $\mathrm{CO}_{2}$ level (Ahmadi and Siosemardeh, 2005).

\section{Antioxidant activity}

Antioxidant activity was measured and expressed as gallic acid (equivalents I of gallic acid/g) with UVVIS spectrophotometer (Shimadzu UV160A-Japan). Three $\mathrm{mg}$ of sample were dissolved in $5 \mathrm{~mL}$ methanol stock, and $1.4 \mathrm{ml}$ of this solution was blended with $0.6 \mathrm{~mL}$ of DPPH solution. After $30 \mathrm{~min}$, the absorbance of the solution was recorded at $515 \mathrm{~nm}$ by the spectrophotometer (UV 160A-Shimadzu Corp., Kyoto, Japan) against methanol as a blank. The $0.2 \mathrm{mM}$ of DPPH solution in methanol was used as a stock of DPPH for the determination of the free radical scavenging activity of the samples (Koleva et al., 2002).

\section{Phenolic content}

Total phenolic content was determined using the Folin-Ciocalteu method. The absorbance was measured at $725 \mathrm{~nm}$ with a spectrophotometer (UV
160A- Shimadzu Corp., Kyoto, Japan). The results were expressed in gallic acid equivalents $(\mathrm{mg} / 100 \mathrm{~g}$ fresh weight) using gallic acid $(0-0.1 \mathrm{mg} / \mathrm{mL})$ standard curve (Singleton et al., 1965).

\section{Proline}

Proline accumulation was determined using the method proposed by Bates et al. (1973). After the extraction of toluene, the clear phase was recovered and spectrophotometrically estimated at $520 \mathrm{~nm}$ using toluene as a blank. Purified proline was used for standardization $(0-50 \mathrm{mg} / \mathrm{mL})$ and was expressed as mol proline $\mathrm{g}^{-1}$ fresh weight.

\section{Electrolyte leakage}

Electrolyte leakage (EL) was measured using an electrical conductivity meter employing the method described by Lutts et al. (1995)

\section{Relative water content}

Relative water content (RWC\%) was determined using ten $7 \mathrm{~mm}$-diameter leaf discs. The leaf discs of each treatment were weighed (FW). They were then hydrated until saturation was reached (constant weight) for $48 \mathrm{~h}$ at $5^{\circ} \mathrm{C}$ in darkness (TW). The leaf discs were dried in an oven at $105^{\circ} \mathrm{C}$ for $24 \mathrm{~h}$ (DW). Relative water content was calculated according to the following equation (Filella et al., 1998):

$$
\text { RWC } \%=(F W-D W) /(T W-D W) \times 100
$$

The determination of total nitrogen in the leaf samples was based on the Kjeldahl method (Estan et al., 2005). The concentrations of $\mathrm{K}, \mathrm{Ca}, \mathrm{Mg}$, and $\mathrm{P}$ were measured (Shield Torch System, Agilent 7500a). Meanwhile, phosphorus was estimated by the vanadomolybdo phosphoric acid colorimetric method at $460 \mathrm{~nm}$ (Estan et al., 2005). P was colorimetrically determined using a spectrophotometer (UV 160A- Shimadzu Corp., Kyoto, Japan).

\section{Statistical analysis}

All data were analyzed using two-way ANOVA (Statistix 8 software) (Tallahassee FL, USA) and the means were compared for the significance by the least significant difference (LSD) test at $P<0.05$.

\section{Results and Discussion}

Analysis of variance of temperature and rootstock on some characteristics of cucumber

Temperature effect shoot fresh and dry weight, chlorophyll index, and the number of the female flower, photosynthetic rate, transpiration, stomatal 
conductance, RWC, EL, phenol content, and all nutrient concentration (Table $1 \mathrm{a}, \mathrm{b}$ ). Rootstock changes all cucumber characteristics except for average fruit weight, fruit diameter, TSS, firmness, mesophyll conductance, proline, and antioxidant (Table $1 \mathrm{a}, \mathrm{b}$ ). The interactive effect of temperature and rootstock showed that all measured parameters change significantly (Table $1 \mathrm{a}, \mathrm{b}$ ).

\section{The main effect of temperature on cucumber}

Shoot fresh and dry weight, chlorophyll, RWC, transpiration, decreased with temperature stress. The number of the female flower, EL, photosynthesis, and stomatal conductance increased with Ts (Table 2 a). First fruit emergence per plant, N, P, K, Mg concentration decreased with Ts stress (Table $2 \mathrm{~b}$ ). Shoot fresh and dry weight and fresh root weight was high-

Table 1 a - Analysis of variance of the effect of temperature and rootstock on some characteristics of cucumber

\begin{tabular}{|c|c|c|c|c|c|c|c|c|c|c|c|c|c|c|}
\hline Source & df & $\begin{array}{l}\text { Shoot } \\
\text { fresh } \\
\text { weight }\end{array}$ & $\begin{array}{l}\text { Shoot } \\
\text { dry } \\
\text { weight }\end{array}$ & $\begin{array}{c}\text { Root } \\
\text { fresh } \\
\text { weight }\end{array}$ & Chl & $\begin{array}{l}\text { Number of } \\
\text { female } \\
\text { flowers }\end{array}$ & $\begin{array}{l}\text { Number } \\
\text { of male } \\
\text { flowers }\end{array}$ & $\begin{array}{c}\text { Fruit } \\
\text { number }\end{array}$ & $\begin{array}{l}\text { Fruit } \\
\text { yield }\end{array}$ & $\begin{array}{c}\text { First } \\
\text { fruit per } \\
\text { plant }\end{array}$ & $\begin{array}{c}\text { Average } \\
\text { fruit } \\
\text { weight }\end{array}$ & $\begin{array}{c}\text { Fruit } \\
\text { diameter }\end{array}$ & TSS & Firmness \\
\hline Temperature & 1 & $3203.42 *$ & $230.9 * *$ & 244.56 NS & $43.12 * *$ & $78.12 *$ & $6.12 \mathrm{~ns}$ & 230. 9 NS & 1441.5 NS & $152.91 *$ & 1971.09 NS & $0.002 \mathrm{NS}$ & $0.30 \mathrm{NS}$ & 7.65 NS \\
\hline Rootstock & 3 & $2467.99 *$ & $23.45^{*}$ & $150.01 *$ & $35.93 * *$ & $602.45 * *$ & $13.08 * *$ & $23.45^{*}$ & 19335 * & $92.57^{*}$ & 2094.59 NS & $0.10 \mathrm{NS}$ & 0.18 NS & 2.07 NS \\
\hline$T \times R$ & 3 & $1327.25 *$ & $26.54 * *$ & $111.77^{* *}$ & $4.65 * *$ & $81.12 * *$ & $4.20 *$ & $26.54 * *$ & $11769.1 * *$ & $4.81 * *$ & $2133.88 *$ & $0.04 * *$ & $0.01 * *$ & $1.23 * *$ \\
\hline Error & 18 & 708.05 & 5.27 & 67.38 & 3.23 & 76.32 & 1.35 & 5.27 & 5110.2 & 17.23 & 1292.36 & 0.04 & 0.12 & 4.26 \\
\hline CV & & 10.30 & 25.62 & 13.04 & 15.50 & 13.97 & 14.38 & 25.62 & 18.03 & 26.05 & 18.65 & 6.77 & 13.40 & 25.25 \\
\hline
\end{tabular}

NS= no significant, $*$ significant at $5 \%$ and $* *$ significant at $1 \%$.

Table $1 \mathrm{~b}$ - Analysis of variance of the effect of temperature and rootstock on some characteristics of cucumber

\begin{tabular}{|c|c|c|c|c|c|c|c|c|c|c|c|c|c|c|c|c|}
\hline Source & $d f$ & $\begin{array}{l}\text { Photo- } \\
\text { synthetic } \\
\text { rate }\end{array}$ & $\begin{array}{c}\text { Tran- } \\
\text { spiration }\end{array}$ & $\begin{array}{l}\text { Stomata } \\
\text { conduc- } \\
\text { tance }\end{array}$ & $\begin{array}{l}\text { Mesophyll } \\
\text { conduc- } \\
\text { tance }\end{array}$ & RWC & EL & Proline & $\begin{array}{c}\text { Anti- } \\
\text { oxidant } \\
\text { activity }\end{array}$ & $\begin{array}{l}\text { Phenol } \\
\text { content }\end{array}$ & $\begin{array}{c}\mathrm{N} \\
\text { Conc. }\end{array}$ & $\begin{array}{c}\mathrm{P} \\
\text { Conc. }\end{array}$ & $\begin{array}{c}\mathrm{K} \\
\text { Conc. }\end{array}$ & $\begin{array}{c}\mathrm{Ca} \\
\text { Conc. }\end{array}$ & $\begin{array}{c}\mathrm{Mg} \\
\text { Conc. }\end{array}$ & $\begin{array}{c}\mathrm{Na} \\
\text { Conc. }\end{array}$ \\
\hline Temperature & 1 & $47.52 *$ & $10.52 * *$ & $0.002 * *$ & 240063 NS & $0.006 * *$ & $257.36 * *$ & 3.27 NS & $0.06 \mathrm{NS}$ & $55824.1 * *$ & $0.72 * *$ & $0.036 * *$ & $0.06 * *$ & $0.15 * *$ & $0.16 * *$ & $0.039 * *$ \\
\hline Rootstock & 3 & $25.08 *$ & $2 * *$ & $0.001 *$ & 26980 NS & $0.001 * *$ & $60.38 * *$ & 1.31 NS & $0.006 \mathrm{NS}$ & $5561.8 * *$ & $1.39 * *$ & $0.03 * *$ & $2.06 * *$ & $0.65 * *$ & $0.07^{* *}$ & $0.01 * *$ \\
\hline$T \times R$ & 3 & $14.25 * *$ & $1.12 * *$ & $0.002 * *$ & $4898 * *$ & $0.0008 * *$ & $72.71 * *$ & $2.82 * *$ & $0.02 * *$ & $4553.6 * *$ & $0.54 * *$ & $0.01 * *$ & $0.62 * *$ & $0.54 * *$ & $0.06 * *$ & $0.008 * *$ \\
\hline Error & 18 & 6.17 & 0.97 & 0.001 & 14354 & 0.00003 & 9.38 & 1.05 & 0.03 & 52.2 & 6.53 & 4.71 & 5.08 & 3.85 & 1.05 & 2.78 \\
\hline$C V$ & & 14.41 & 14.82 & 17.80 & 38.05 & 0.74 & 7.56 & 11.03 & 5.81 & 5.01 & 12.1 & 26.7 & 21.5 & 7.87 & 6.23 & 16.9 \\
\hline
\end{tabular}

NS= no significant, ${ }^{*}$ significant at $5 \%$ and ${ }^{* *}$ significant at $1 \%$.

Table 2 a -The effect of temperature on some characteristics of cucumber

\begin{tabular}{|c|c|c|c|c|c|c|c|c|c|}
\hline $\begin{array}{l}\text { Temperature } \\
\left({ }^{\circ} \mathrm{C}\right)\end{array}$ & $\begin{array}{l}\text { Shoot fresh } \\
\text { weight } \\
\text { (g) }\end{array}$ & $\begin{array}{l}\text { Shoot dry } \\
\text { weight } \\
\text { (g) }\end{array}$ & $\begin{array}{l}\text { Chl } \\
\text { (SPAD } \\
\text { value) }\end{array}$ & $\begin{array}{l}\text { Number of } \\
\text { the female } \\
\text { flower }\end{array}$ & $\begin{array}{l}\text { El } \\
(\%)\end{array}$ & $\begin{array}{l}\text { RWC } \\
(\%)\end{array}$ & $\begin{array}{c}\text { Transpiration } \\
\left(\mathrm{mmol} \mathrm{H}_{2} \mathrm{O} \mathrm{m}^{-2} \mathrm{~s}^{-1}\right)\end{array}$ & $\begin{array}{l}\text { Photosynthetic rate } \\
\left(\mathrm{mmol} \mathrm{H}_{2} \mathrm{Om}^{-2} \mathrm{~s}^{-1}\right)\end{array}$ & $\begin{array}{c}\text { Stomata } \\
\text { conductance } \\
\left(\mathrm{mmol} \mathrm{H}_{2} \mathrm{Om}^{-2} \mathrm{~s}^{-1}\right)\end{array}$ \\
\hline Tc & $76.52 \mathrm{a}$ & $11.71 \mathrm{a}$ & $12.7 \mathrm{a}$ & $2.18 \mathrm{~b}$ & $37.1 \mathrm{~b}$ & 0.79 a & $2.83 \mathrm{a}$ & $4.16 b$ & $61.31 b$ \\
\hline Ts & $55.53 b$ & $6.21 \mathrm{~b}$ & $10.4 \mathrm{~b}$ & $3.06 \mathrm{a}$ & $43.91 \mathrm{a}$ & $0.75 b$ & $1.57 \mathrm{~b}$ & $7.02 \mathrm{a}$ & $177.34 \mathrm{a}$ \\
\hline
\end{tabular}

$\mathrm{Tc}=$ optimum temperature, $\mathrm{Ts}=$ low temperature.

Within a column means followed by the same letter are not significantly different at $\mathrm{P}<5 \%$ according to LSD test.

Table $2 \mathrm{~b}$ - The effect of temperature on some characteristics of cucumber

\begin{tabular}{|c|c|c|c|c|c|c|c|c|}
\hline Temperature $\left({ }^{\circ} \mathrm{C}\right)$ & $\begin{array}{c}\text { First fruit } \\
\text { emergence per } \\
\text { plant (day) }\end{array}$ & $\begin{array}{c}\text { Phenol } \\
\left(\mathrm{mgg}^{1} \mathrm{FW}\right)\end{array}$ & $\begin{array}{c}\mathrm{N} \\
(\%)\end{array}$ & $\begin{array}{l}P \\
(\%)\end{array}$ & $\begin{array}{c}\mathrm{K} \\
(\%)\end{array}$ & $\begin{array}{l}\mathrm{Ca} \\
(\%)\end{array}$ & $\begin{array}{l}\mathrm{Mg} \\
(\%)\end{array}$ & $\begin{array}{l}\mathrm{Na} \\
(\%)\end{array}$ \\
\hline Tc & 19.57 a & $17.69 \mathrm{~b}$ & $3.51 \mathrm{a}$ & $0.43 a$ & $3.11 \mathrm{a}$ & $1.54 \mathrm{~b}$ & $0.74 a$ & $0.14 \mathrm{~b}$ \\
\hline Ts & $12.30 \mathrm{~b}$ & $271.06 \mathrm{a}$ & $3.37 b$ & $0.39 \mathrm{~b}$ & $2.54 \mathrm{~b}$ & $1.66 \mathrm{a}$ & $0.68 \mathrm{~b}$ & $0.21 \mathrm{a}$ \\
\hline
\end{tabular}

Tc= optimum temperature; Ts= low temperature.

Within a column means followed by the same letter are not significantly different at P<5\% according to LSD test. 
est in Rma, the number of male flower increased in $\mathrm{Rn}$ and $\mathrm{Rs}$ and female flower increased in Rmo and Rma.

\section{The main effect of rootstock on cucumber}

The highest $\mathrm{El}$ and photosynthesis were observed in Rmo. The RWC and stomata conductance increased in Rma and Rmo, however, transpiration increased in Rs, Rmo, and Rma (Table 3 a). N, P, K, Ca, and phenol increased in Rma and Rmo. Mg was at the highest concentration in $\mathrm{Rma}$ and $\mathrm{Na}$ in $\mathrm{Rn}$ (Table
$3 \mathrm{~b})$. Rma has the highest fruit number, fruit yield, although, first fruit emerges in Rmo (Table 4).

The interaction effect of temperature and cucumber grafting on some growth characteristics of cucumber

$\mathrm{K}$ concentration was the highest in Rmo in both temperatures and $\mathrm{P}$ concentration increased in RmaxTs. The highest $\mathrm{N}, \mathrm{K}$ and $\mathrm{Ca}$, concentrations were seen in RmaxTs. $P$ concentration increased in Rma and Rmo at Ts. Mg increased in RsxTc and $\mathrm{Na}$ in Rs $\times$ Ts (Table 5).

Table 3 a -The effect of rootstock on some characteristics of cucumber

\begin{tabular}{|c|c|c|c|c|c|c|c|c|c|c|}
\hline Rootstock & $\begin{array}{l}\text { Shoot fresh } \\
\text { weight } \\
\text { (g) }\end{array}$ & $\begin{array}{l}\text { Shoot dry } \\
\text { weight } \\
\text { (g) }\end{array}$ & $\begin{array}{l}\text { Root fresh } \\
\text { weight } \\
\text { (g) }\end{array}$ & $\begin{array}{l}\text { Number of } \\
\text { male } \\
\text { flowers }\end{array}$ & $\begin{array}{l}\text { Number of } \\
\text { female } \\
\text { flower }\end{array}$ & $\begin{array}{l}\text { El } \\
(\%)\end{array}$ & $\begin{array}{l}\text { RWC } \\
\text { (\%) }\end{array}$ & $\begin{array}{c}\text { Photosynthetic } \\
\text { rate } \\
(\mu \mathrm{mol} \\
\left.\mathrm{CO}_{2} \mathrm{~m}^{-2} \mathrm{~s}^{-1}\right)\end{array}$ & $\begin{array}{c}\text { Transpiration } \\
(\mathrm{mmol} \\
\left.\mathrm{H}_{2} \mathrm{O} \mathrm{m}^{-2} \mathrm{~s}^{-1}\right)\end{array}$ & $\begin{array}{c}\text { Stomata } \\
\text { conductance } \\
\text { (mmol } \mathrm{H}_{2} \mathrm{O} \\
\left.\mathrm{m}^{-2} \mathrm{~s}^{-1}\right) \\
\end{array}$ \\
\hline $\mathrm{Rn}$ & $61.28 \mathrm{~b}$ & $8.23 \mathrm{~b}$ & $16.78 \mathrm{~b}$ & $23.50 \mathrm{a}$ & $2.37 \mathrm{~b}$ & $38.98 \mathrm{bc}$ & $0.76 \mathrm{~b}$ & $4.94 \mathrm{~b}$ & $1.65 \mathrm{~b}$ & $78.79 \mathrm{~b}$ \\
\hline Rs & $55.48 \mathrm{~b}$ & $9.29 a b$ & $17.96 \mathrm{ab}$ & $23 a$ & $1.75 \mathrm{~b}$ & $41.67 \mathrm{ab}$ & $0.76 b$ & $3.83 \mathrm{~b}$ & $2.69 \mathrm{a}$ & $71.94 \mathrm{~b}$ \\
\hline Rma & $92.34 \mathrm{a}$ & $11.17 \mathrm{a}$ & $18.21 \mathrm{a}$ & $5.5 \mathrm{~b}$ & $4.5 \mathrm{a}$ & $37.10 \mathrm{c}$ & $0.78 \mathrm{a}$ & $4.84 \mathrm{~b}$ & $1.86 \mathrm{ab}$ & $89.96 a b$ \\
\hline Rmo & $55 b$ & $7.14 \mathrm{~b}$ & $17.95 \mathrm{~b}$ & $12.75 \mathrm{~b}$ & $3.87 \mathrm{ab}$ & $44.38 \mathrm{a}$ & $0.78 a$ & $8.75 a$ & $2.61 \mathrm{ab}$ & $126.62 \mathrm{a}$ \\
\hline
\end{tabular}

$\mathrm{Rn}=$ nongrafted (Cucumis sativus var. DavosII);

$\mathrm{Rs}=$ self grafted;

Rma= Cucurbita maxima;

Rmo $=$ Momordica charantia .

Within a column means followed by the same letter are not significantly different at $\mathrm{P}<5 \%$ according to LSD test.

Table $3 \mathrm{~b}$ - The effect of rootstock on some characteristics of cucumber

\begin{tabular}{lccccccc}
\hline Rootstock & $\begin{array}{c}\text { Phenol } \\
\left(\mathrm{mgg}^{1} \mathrm{FW}\right)\end{array}$ & $\begin{array}{c}\mathrm{N} \\
(\%)\end{array}$ & $\begin{array}{c}\mathrm{P} \\
(\%)\end{array}$ & $\begin{array}{c}\mathrm{K} \\
(\%)\end{array}$ & $\begin{array}{c}\mathrm{Ca} \\
(\%)\end{array}$ & $\begin{array}{c}\mathrm{Mg} \\
(\%)\end{array}$ & $\begin{array}{c}\mathrm{Na} \\
(\%)\end{array}$ \\
\hline Rn & $124.54 \mathrm{bc}$ & $3.19 \mathrm{c}$ & $0.45 \mathrm{~b}$ & $2.52 \mathrm{~d}$ & $1.05 \mathrm{~d}$ & $0.70 \mathrm{~b}$ & $0.19 \mathrm{a}$ \\
Rs & $112.19 \mathrm{c}$ & $3.08 \mathrm{~d}$ & $0.38 \mathrm{c}$ & $2.55 \mathrm{c}$ & $1.32 \mathrm{c}$ & $0.69 \mathrm{c}$ & $0.20 \mathrm{a}$ \\
Rma & $133.90 \mathrm{~b}$ & $3.85 \mathrm{a}$ & $0.47 \mathrm{a}$ & $3.65 \mathrm{a}$ & $2.11 \mathrm{a}$ & $0.51 \mathrm{~d}$ & $0.14 \mathrm{c}$ \\
Rmo & $206.87 \mathrm{a}$ & $3.64 \mathrm{~b}$ & $0.33 \mathrm{~d}$ & $2.57 \mathrm{~b}$ & $1.89 \mathrm{~b}$ & $0.93 \mathrm{a}$ & $0.18 \mathrm{~b}$ \\
\hline
\end{tabular}

$\mathrm{Rn}=$ nongrafted (Cucumis sativus var. DavosII);

Rs= self grafted;

Rma= Cucurbita maxima;

Rmo $=$ Momordica charantia

Within a column means followed by the same letter are not significantly different at $\mathrm{P}<5 \%$ according to LSD test.

Table 4 - The effect of rootstock on some characteristics of cucumber

\begin{tabular}{lccc}
\hline Rootstock & $\begin{array}{c}\text { Fruit } \\
\text { number }\end{array}$ & $\begin{array}{c}\text { Fruit } \\
\text { yield } \\
(\mathrm{g})\end{array}$ & $\begin{array}{c}\text { First fruit } \\
\text { emergence per } \\
\text { plant (day) }\end{array}$ \\
\hline Rn & $0.8 \mathrm{~b}$ & $63.88 \mathrm{~b}$ & $21.51 \mathrm{a}$ \\
$\mathrm{Rma}$ & $2.00 \mathrm{a}$ & $159.50 \mathrm{a}$ & $15.29 \mathrm{ab}$ \\
$\mathrm{Rmo}$ & $1.37 \mathrm{ab}$ & $91.88 \mathrm{ab}$ & $11.00 \mathrm{~b}$ \\
\hline
\end{tabular}

$\mathrm{Rn}=$ nongrafted (Cucumis sativus var. DavosII);

$\mathrm{Rs}=$ self grafted did not have any fruit;

Rma= Cucurbita maxima;

Rmo $=$ Momordica charantia.

Within a column means followed by the same letter are not significantly different at $\mathrm{P}<5 \%$ according to LSD test.
Shoot fresh weights decreased in $\mathrm{Rn}$ and $\mathrm{Rs}$ at low temperatures (Ts), but shoot dry weights did not significantly change in Rma and Rmo at both temperatures (Fig. 1). Shoot dry weights followed the same trend as the fresh shoot weight was the highest in Rn, Rs, Rma at Tc (Fig. 1). Root fresh weights decreased in Rn, Rs, and Rma at Ts compared with Tc, but did not significantly change in Rmo at both temperatures, although the fresh root weight was the lowest in Rmo at Tc. The highest root fresh weight was seen in RmaxTc (Fig. 2 a).

SPAD value was the highest in Rs, Rma, and Rmo at Tc (Fig. 2 b). The interaction effect of the tempera- 
Table 5 - The interaction effect of temperature and cucumber grafting on some elements concentration (\%) of leaves

\begin{tabular}{|c|c|c|c|c|c|c|c|c|c|c|c|c|}
\hline \multirow{2}{*}{ Rootstock } & \multicolumn{2}{|c|}{$\mathrm{N}$} & \multicolumn{2}{|c|}{$P$} & \multicolumn{2}{|c|}{$\mathrm{K}$} & \multicolumn{2}{|c|}{$\mathrm{Ca}$} & \multicolumn{2}{|c|}{$\mathrm{Mg}$} & \multicolumn{2}{|c|}{$\mathrm{Na}$} \\
\hline & Tc & Ts & Tc & Ts & Tc & Ts & Tc & Ts & Tc & Ts & Tc & Ts \\
\hline $\mathrm{Rn}$ & $3.36 \mathrm{~d}$ & $3.03 \mathrm{e}$ & $0.37 c$ & $0.35 c$ & $2.50 \mathrm{f}$ & $2.75 \mathrm{e}$ & $1.28 \mathrm{C}$ & $0.83 \mathrm{~g}$ & $0.81 b$ & $0.58 \mathrm{c}$ & $0.18 \mathrm{c}$ & $0.21 b$ \\
\hline Rs & $3.08 \mathrm{e}$ & $3.08 \mathrm{e}$ & $0.33 \mathrm{c}$ & $0.34 \mathrm{c}$ & $3.00 \mathrm{~d}$ & $2.15 \mathrm{~g}$ & $1.65 \mathrm{~b}$ & $1.00 \mathrm{e}$ & $0.88 a$ & $0.51 \mathrm{e}$ & $0.12 \mathrm{f}$ & $0.28 a$ \\
\hline Rma & $3.78 \mathrm{c}$ & $4.2 \mathrm{a}$ & $0.34 \mathrm{c}$ & $0.52 a$ & $3.45 b$ & $3.69 \mathrm{a}$ & $1.24 \mathrm{~d}$ & $1.75 \mathrm{a}$ & $0.51 \mathrm{e}$ & $0.57 \mathrm{~d}$ & $0.12 \mathrm{f}$ & $0.14 \mathrm{e}$ \\
\hline Rmo & $3.98 \mathrm{~b}$ & $3.78 \mathrm{c}$ & $0.42 \mathrm{~b}$ & $0.48 a$ & $3.25 \mathrm{c}$ & $3.10 \mathrm{~cd}$ & $0.83 \mathrm{~g}$ & $0.87 f$ & $0.56 \mathrm{~d}$ & $0.50 \mathrm{e}$ & $0.09 \mathrm{~g}$ & $0.16 d$ \\
\hline
\end{tabular}

$\mathrm{Rn}=$ nongrafted (Cucumis sativus var. DavosII);

$\mathrm{Rs}=$ self grafted;

Rma $=$ Cucurbita maxima;

$\mathrm{Rmo}=$ Momordica charantia .

Within a column means followed by the same letter are not significantly different at $\mathrm{P}<5 \%$ according to LSD test.

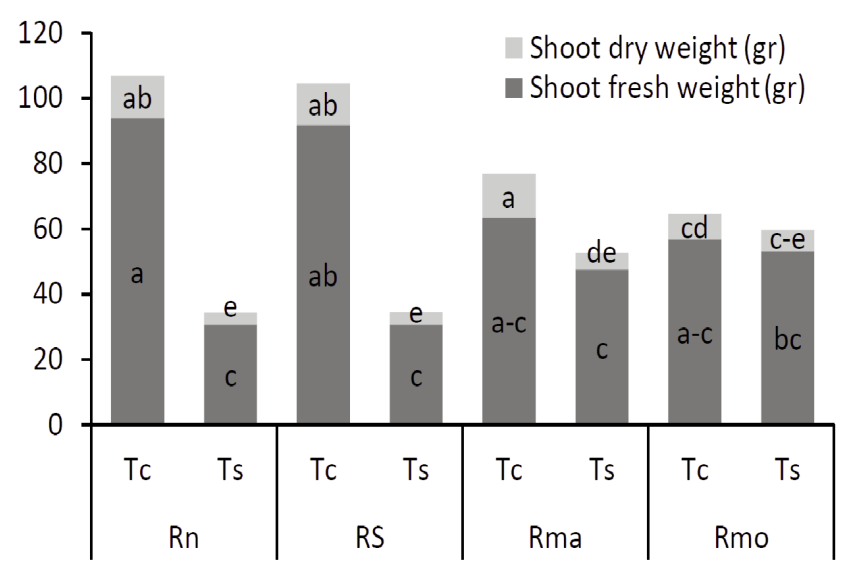

Fig. 1 - The interaction effect of temperature and cucumber grafting on shoot fresh and dry weight. Tc= optimum temperature; $\mathrm{Ts}=$ low temperature; $\mathrm{Rn}=$ nongrafted (Cucumis sativus var. DavosII); Rs= self grafted; Rma= Cucurbita maxima; Rmo= Momordica charantia.

ture on grafted cucumber did not significantly affect the time of the emergence of the first female flowers (data did not show). The highest and the lowest number of the male flower were seen in RsxTc and Rma, respectively. The female flower was affected by temperature variations in different rootstocks. The female flower increased in the Rn and Rma at Ts and did not change in Rs and Rmo at Tc and Ts (Fig. 3).

Fruit number was the highest in RmaxTc, although the same results were seen in RmoxTc and Rmo and Rma at Ts (Fig. 4 a). Fruit yield was the highest in RmaxTc; the same result was statically seen in Rma $\times$ Ts (Fig. 4 b).

First, fruit emergence time significantly decreased in grafted plants at this temperature (Fig. 5). The highest fruit weight was in RmaxTc; fruit diameter did not significantly change between treatments (Fig. 6). TSS increased in Rn and Rmo at Ts (Fig. 7 a). Firmness decreased in RmoxTs (Fig. 7 b) results, Goreta et al. (2008) found that shoot weight reduc-

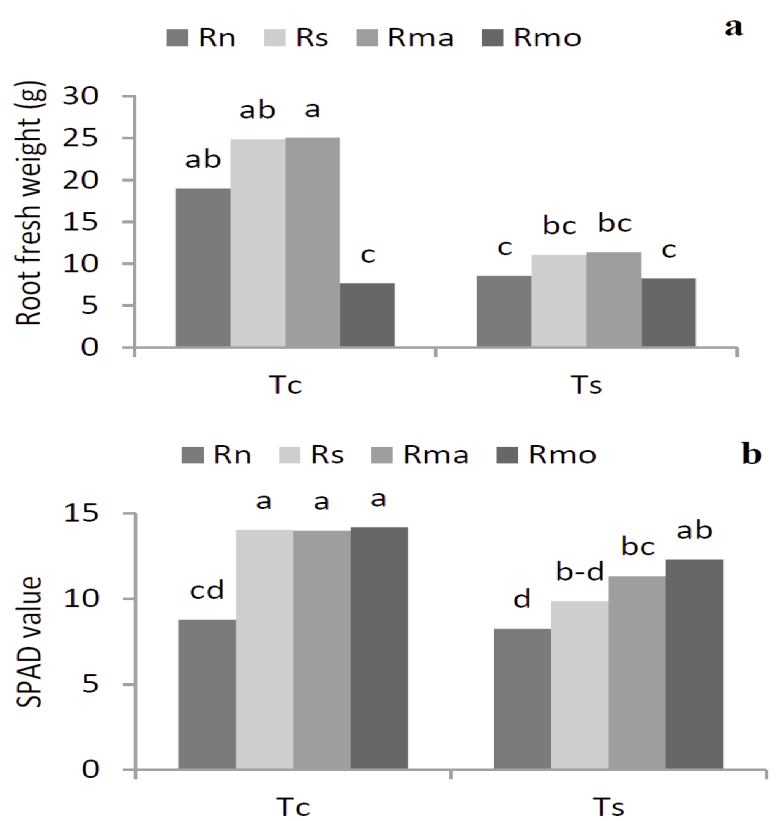

Fig. 2 - The interaction effect of temperature and cucumber grafting on root fresh weight (a) and SPAD value (b) Tc= optimum temperature; $\mathrm{Ts}=$ low temperature; $\mathrm{Rn}=$ nongrafted (Cucumis sativus var. Davos II); Rs= self grafted; $\mathrm{Rma}=$ Cucurbita maxima; Rmo= Momordica charantia.

tion in watermelon grafted onto Cucurbita maxima Duch. $\times$ Cucurbita moschata Duch was less) than nongrafted plants under salt stresses. The grafted cucumber plants showed less change in shoot and root weights under $\mathrm{Cu}$ stress conditions and this might be due to the lower accumulation of $\mathrm{Cu}$ in leaves through their squash rootstocks (Rouphael et al., 2008).

The lowest male flower was seen in Rma at both temperatures (Fig. 3). Conversely, the highest number of female flowers was observed in Rma at Ts and Tc compared with other rootstocks at each temperature. On the other hand, at the optimum temperature $(T c)$, each rootstock had a lower female flower 


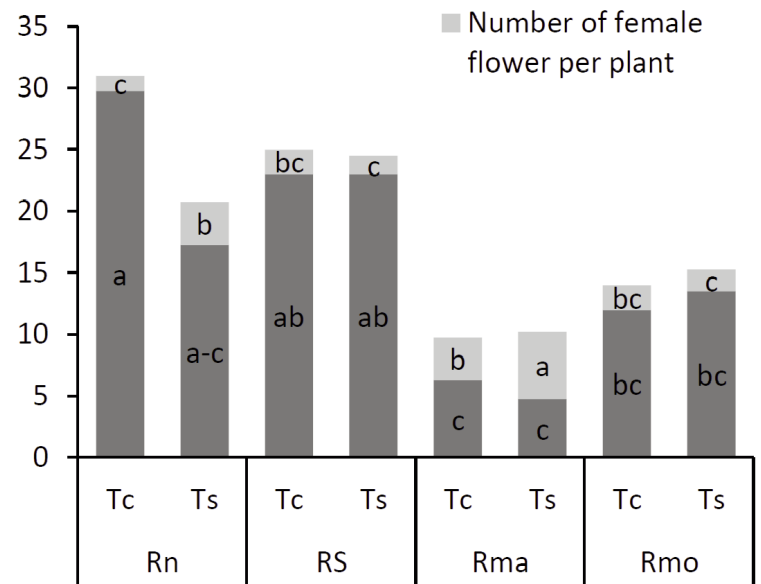

Fig. 3 - The interaction effect of temperature and cucumber grafting male and female flower number. $\mathrm{Tc}=$ optimum temperature; $\mathrm{Ts}=$ low temperature; $\mathrm{Rn}=$ nongrafted (Cucumis sativus var. DavosII); Rs= self grafted; $\mathrm{Rma}=$ Cucurbita maxima; Rmo= Momordica charantia.
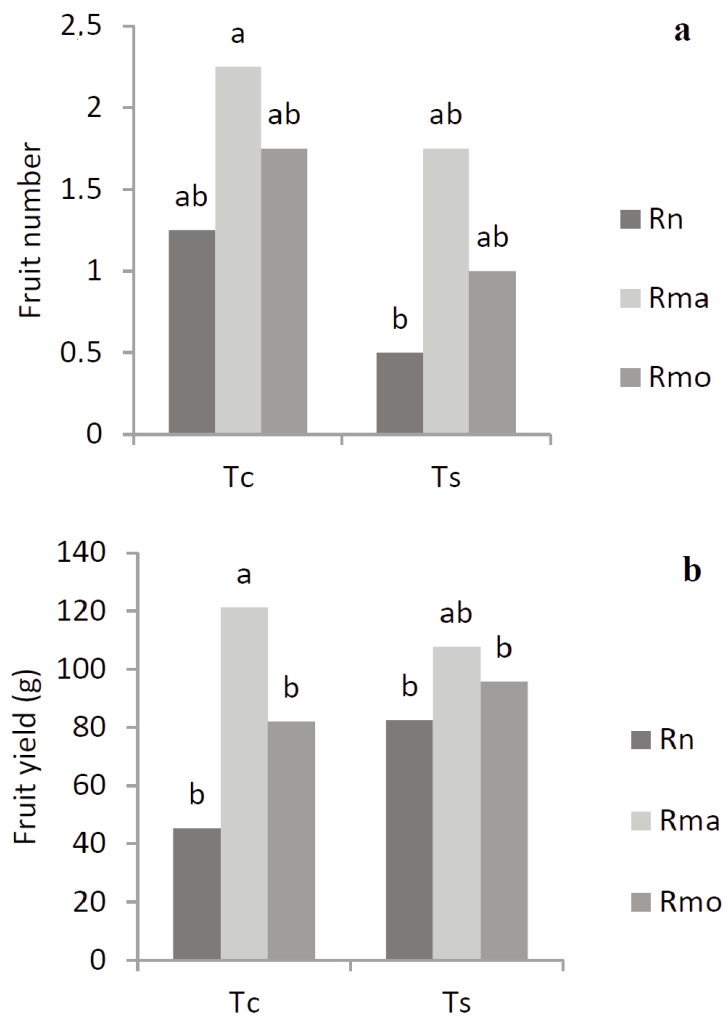

Fig. 4 - The interaction effect of temperature and cucumber grafting on fruit number (a) and fruit yield (b) Momordica charantia Rs did not have fruit. Tc= optimum temperature; Ts= low temperature; $\mathrm{Rn}=$ nongrafted (Cucumis sativus var. DavosII); Rs= self grafted; Rma= Cucurbita maxima; Rmo= Momordica charantia.

showed the highest male flower. Van der Ploeg and Heuvelink (2005) reported that low temperatures reduced the tomato fruit set through poor pollen quality and increased the period between anthesis and fruit maturity resulting in lower fruit yields. The result of Khah et al. (2006) showed that tomatoes cv. Big Red grafted onto cv. Heman and Primavera produced more fruit at low temperatures compared to non-grafted plants in greenhouse conditions. In our study, fruit number decreased at Ts and grafting had a beneficial effect on fruit number, but did not influence fruit yields. In agreement with our study, commercial tomato grafting was not able to improve the reduction of tomato yields under low light stresses by shading (Krumbein and Schwarz, 2013).

The economic increase of yield imparted by select vigorous commercial rootstocks (Kyriacou et al., 2017) like increasing tomato yields was observed by

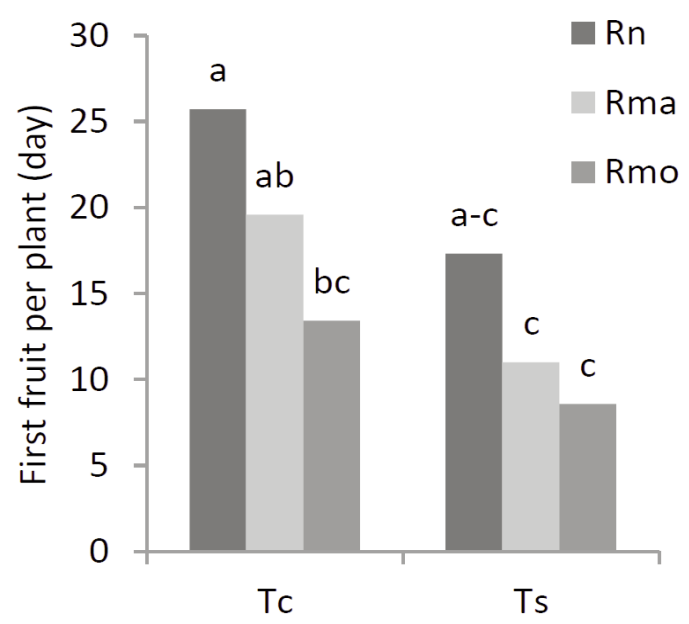

Fig. 5 - The interaction effect of temperature and cucumber grafting on the first fruit emergence of a plant. Tc= optimum temperature; $\mathrm{Ts}=$ low temperature; $\mathrm{Rn}=$ nongrafted (Cucumis sativus var. DavosII); Rs= self grafted; Rma= Cucurbita maxima; Rmo= Momordica charantia .

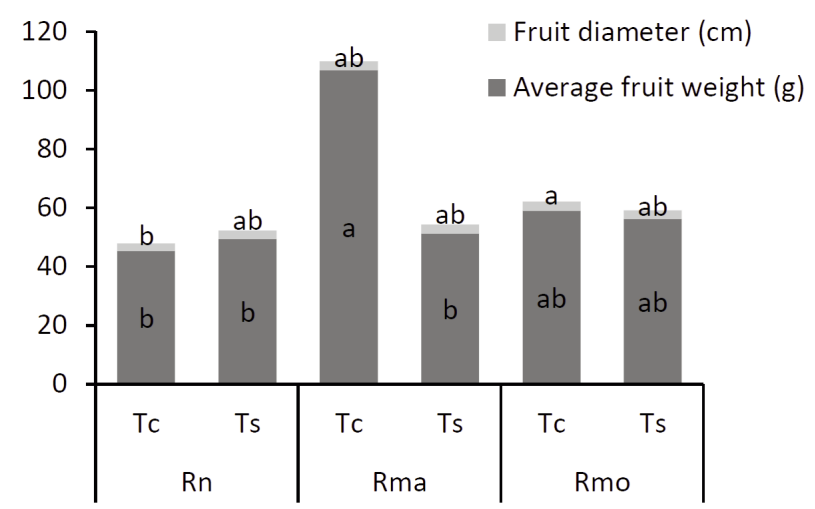

Fig. 6 - The interaction effect of temperature and cucumber grafting on average fruit weight and fruit diameter. $T c=$ optimum temperature; $\mathrm{Ts}=$ low temperature; $\mathrm{Rn}=$ nongrafted (Cucumis sativus var. DavosII); Rs= self grafted; $\mathrm{Rma}=$ Cucurbita maxima; Rmo= Momordica charantia . 
grafting tomatoes onto Kagemusia and Helper's rootstocks by Lee et al. (2007). Santa-Cruz et al. (2001) grafted tomato cv. Moneymaker onto Pera and observed that growth and yield of tomato increased under salt stress conditions. Similar results were observed by Estan et al. (2005), who found that tomato yield increased through grafting under salt stresses and also reported that fruit yield in hetrografted plants increased more compared with selfgrafted plants. Ruiz et al. (1997) believed that increase yield and growth of the grafted plants might be due to an increase in the nutrient and water uptake fed by vigorous rootstock. Huang et al. (2010) reported that cucumbers grafted had a higher fruit yield than non-grafted plants under salt stresses. Colla et al. (2010) found that increasing $\mathrm{CO}_{2}$ assimilation by cucumber grafting increased fruit yields.

The interaction effect of temperature and cucumber grafting on some physiological characteristics and nutrient concentration of cucumber

The photosynthesis rate decreased in $\mathrm{Rn}$ and $\mathrm{Rs}$ at Ts compared with Tc. However, it did not significantly
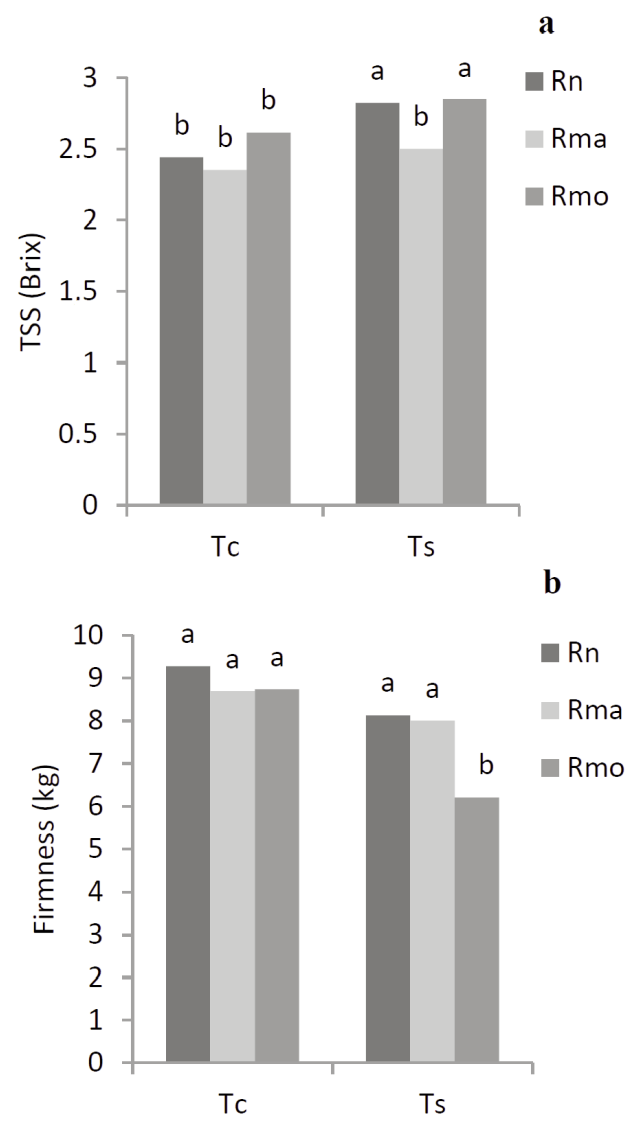

Fig. 7 - The interaction effect of temperature and cucumber grafting on TSS (a) and firmness (b). Tc= optimum temperature, $\mathrm{Ts}=$ low temperature; $\mathrm{Rn}=$ nongrafted (Cucumis sativus var. DavosII); Rs= self grafted; Rma= Cucurbita maxima; Rmo $=$ Momordica charantia. change in Rma and Rmo (Fig. 8 a). Transpiration decreased at Ts in all rootstocks compared with Tc (Fig. 8 b). Stomata conductance gradually increased in Rs, Rma, and Rmo at Ts compared with Tc and reached the highest in RmoxTs (Fig. $8 \mathrm{c}$ ). Mesophyll conductance did not significantly change in each rootstock at Tc and Ts, except for ungrafted cucumbers in which it increased at Ts compared with Tc (Fig. $8 \mathrm{~d}$ ).

El and RWC were generally the lowest and the highest at TS, respectively. the highest EL was seen in RmoxTs. The maximum RWC, at Ts, was observed in Rn, Rma, and Rmo (Fig. 9 a, b). Antioxidant increased in $\mathrm{Rn}$ and $\mathrm{Rs}$ at Ts and did not change in other treat-

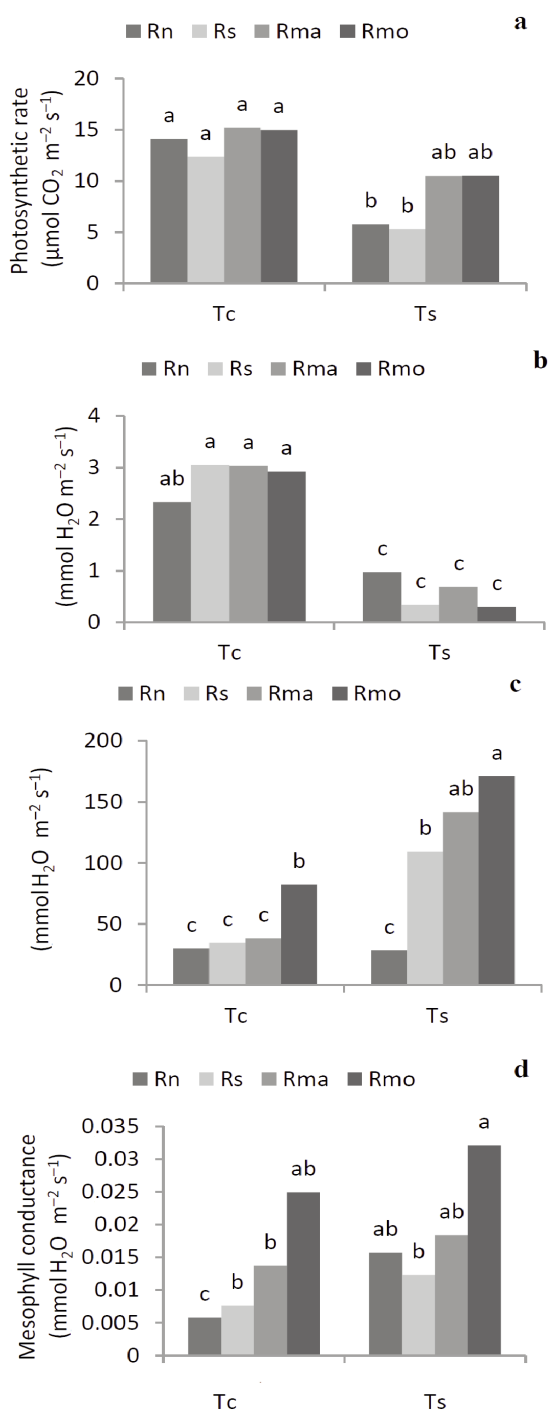

Fig. 8 - The interaction effect of temperature and cucumber grafting on photosynthesis (a), transpiration (b), stomata conductance (c), mesophyll conductance (d) Tc= optimum temperature; $\mathrm{Ts}=$ low temperature; $\mathrm{Rn}=$ nongrafted (Cucumis sativus var. Davosll); Rs= self grafted; $\mathrm{Rma}=$ Cucurbita maxima; Rmo= Momordica charantia . 

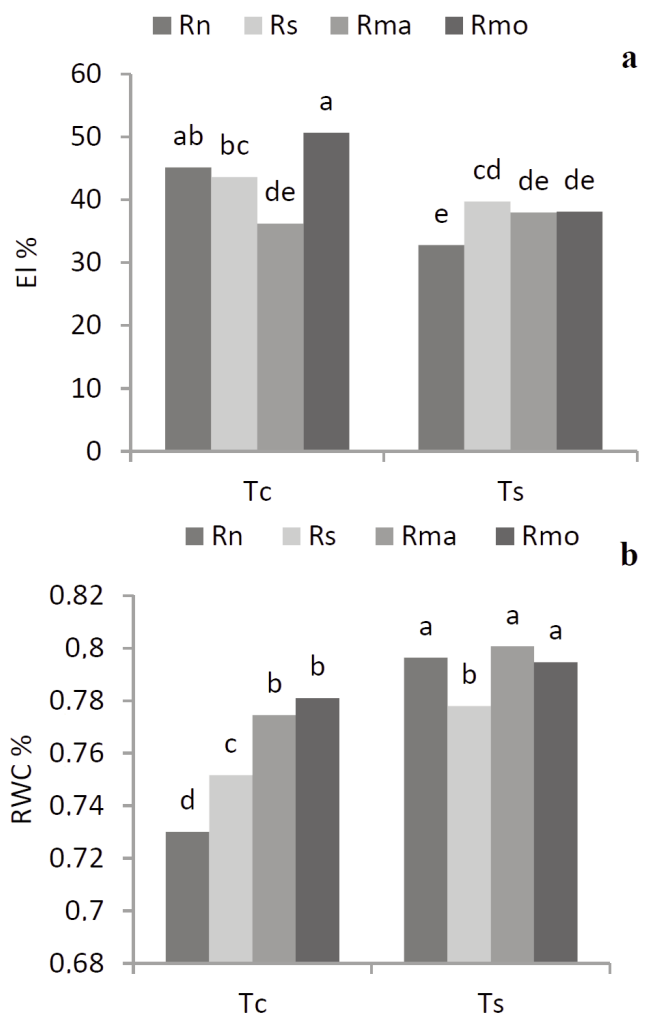

Fig. 9 - The interaction effect of temperature and cucumber grafting on El (a) and RWC (b) Tc= optimum temperature, $\mathrm{Ts}=$ low temperature, $\mathrm{Rn}=$ nongrafted (Cucumis sativus var. DavosII); Rs= (self grafted); Rma= Cucurbita maxima, Rmo $=$ Momordica charantia .

ments (Fig. 10 a). Phenol content increased in all plants at Ts and reached the highest point in RmoxTs (Fig. 10 b). Proline did not significantly change among treatments (Fig. $10 \mathrm{c}$ ).

Increasing antioxidant content with using rootstock was reported by Rouphael et al. (2018); this may help grafted plant to have a better function under different stress.

The photosynthesis rate and SPAD value showed that the SPAD value did not change in Rmo. Thus, photosynthesis did not change. However, the same result was not seen in Rma. Therefore, it seems that another mechanism interfered with the stability of photosynthesis in Rma in this condition rather than changes of chlorophyll content (Fig. 6 a and 7a).

Some researchers demonstrated that the photosynthesis rate was influenced by leaf area, stomatal conductance, and chlorophyll content. In our study, low-temperature stress caused a reduction in SPAD value and resulted in photosynthesis reduction. On the other hand, the photosynthesis in grafted cucumbers having high SPAD value and stomata conductance improved under low-temperature stresses.
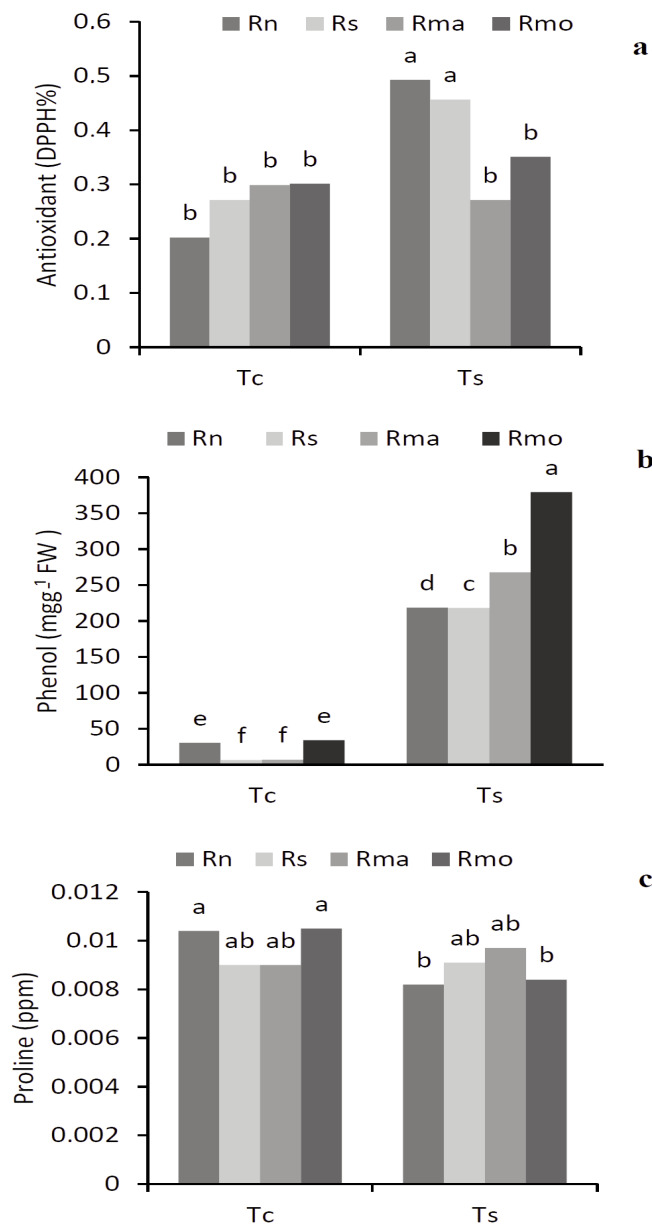

Fig. 10 - The interaction effect of temperature and cucumber grafting on antioxidant (a) and phenol (b) and proline (c) Tc= optimum temperature; $\mathrm{Ts}=$ low temperature; $\mathrm{Rn}=$ nongrafted (Cucumis sativus var. DavosII); Rs= self grafted; Rma= Cucurbita maxima; Rmo= Momordica charantia.

Davis et al. (2008) reported that grafting increased photosynthesis under salt stress conditions too.

Grafted cucumbers showed higher photosynthesis rates, stomatal conductance, and intercellular $\mathrm{CO}_{2}$ under salt stresses compared with non-grafted plants (Yang et al., 2006). Massai et al. (2004) and Moya et al. (2002) reported that grafting improved photosynthesis under salt stress conditions, too. Rootstockinduced changes in stomatal development, as reduced transpiration relates to lower stomatal density in grafted plants (Kumar et al., 2017).

Zhou et al. (2009) reported that increasing the photosynthesis rate by grafting plants onto a different rootstock might be due to a decrease in the ROS concentration in the leaves. Beside, grafting increased water and nutrient uptake of the plant and could enhance its photosynthesis (Martinez-Ballesta 
et al., 2010). Salehi et al. (2010) reported that melon grafting had high $\mathrm{CO}_{2}$ assimilation due to increasing stomata conductance and $\mathrm{Ci}$ and resulted in an increase in photosynthesis.

The photosynthesis rate and the fresh shoot weight of Rmo and Rma did not significantly change at both temperatures. Thus, low temperatures could not affect the photosynthesis rate in Rmo and Rma. On the other hand, decreasing the fresh weight was seen at Ts in Rn due to a decrease of photosynthesis rate in these rootstocks (Fig. 7).

Overall, low stomata and mesophyll conductance of un-grafted cucumbers which have adverse effects on water relation, mineral nutrient uptake and transport (Kumar et al., 2017), carbohydrate and hormone relationship, photosynthesis and respiration rates result in a decline in yields (Kozlowiski, 1984; Barrick and Noble, 1993; Bacanamwo and Purcell, 1999). These results were in line with our results at lowtemperature stresses. Still, when cucumbers were grafted onto Karella they were kept under proper conditions for more efficient photosynthesis, and consequently, a better yield was produced.

The result of the study showed that salinity stresses reduced the $K$ concentration in melons and cucumbers and grafted plants had higher nutrient concentrations than non-grafted plants. Many rootstocks are capable of increasing the uptake and translocation of nutrients (Kumar et al., 2017). In agreement with our result, Colla et al. (2013) reported that cucumber grafting had no influence on $\mathrm{K}$ and $P$ concentrations in the leaves, root, and fruit under salt stresses. Our result showed that the highest $\mathrm{K}$ concentration was in Rmo at both temperatures and $\mathrm{P}$ concentration increased by grafting at Tc.

\section{Conclusions}

It seems that the photosynthetic traits of grafted cucumbers were not affected mainly by Rmo and Rma at stress conditions. On the other hand, hormonal changes or nutrient uptake of these rootstocks seemingly caused lesser root and additional vegetative growth but stimulated more fruit and yields. The effect of these rootstocks on productivity growth resulted in more male flowers than female ones, which was predictable according to the productive growth model of Cucurbitaceae in which male flowers and then female flowers emerged in the bush. Accordingly, if this experiment lasted more, it might result in more female flowers, suggesting that further investigations might be needed. All in all, using Rmo as well as Rma is recommended after testing the fruit quality and the economic yield.

\section{Reference}

AHMADI A., SIOSEMARDEH A., 2005 - Investigation on the physiological basis of grain yield and drought resistance in wheat: Leaf photosynthetic rate, stomatal conductance and non-stomatal limitation. - Int. J. Agric. Biol., 7: 807-811.

BACANAMWO M., PURCELL L.C., 1999 - Soybean root morphological and anatomical traits associated with acclimation to flooding. - Crop Sci., 39: 143-149.

BARRICK K.A., NOBLE M.G., 1993 - The iron and manganese status of seven upper montane tree species in Colorado following long term water logging. - J. Ecol., 81: 523-531.

BATES L.S., WALDREN R.P., TEARE I.D., 1973 - Rapid determination of free proline for water-stress studies. - Plant Soil, 39: 205-207.

BHATT R.M, SRINIVASA-RAO N.K., SADASHIVA A.T., 2002 Rootstock as a source of drought tolerance in tomato (Lycopersicon esculentum Mill). - Indian J. Plant Physiol., 7: 338-342.

COLLA G., ROUPHARL Y., JAWAD R., KUMAR P., REA E., 2013 - The effectiveness of grafting to improve $\mathrm{NaCl}$ and $\mathrm{CaCl}_{2}$ tolerance in cucumber. - Sci. Hort., 164: 380391.

COLLA G., ROUPHARL Y., LEONARDI C., BIE Z., 2010 - Role of grafting in vegetable crops grown under saline conditions. - Sci. Hort., 127: 147-155.

DAVIS A.R., PERKINS-VEAZIE P., DAKATAAKATA Y., LOPEZGALARZA S., MAROTO J.V., LEE S.G., HYHY C., SUN, Z., MIGUEL A., KING S.R., COHEN R., LEE J.M., 2008 Cucurbit grafting. - CRC Crit. Rev. Plant Sci., 27: 50-74.

EDELSTEIN M., BEN-HUR M., COHEN R., BURGER Y., RAVINA I., 2005 - Boron and salinity effects on grafted and non-grafted melon plants. - Plant Soil, 269: 273-284.

ESTAN M.T., MARTINEZ-RODRIGUEZ M.M., PEREZ-ALFOCEA F., FLOWERS T.J., BOALRIN M.C., 2005 - Grafting raises the salt tolerance of tomato through limiting the transport of sodium and chloride to the shoot. Environ. Exp. Bot., 56: 703-712.

FILELLA I., LLUSIA J., PIN J.O., PEN J.U., 1998 - Leaf gas exchange and fluorescence of Phillyrea latifolia, Pistacia lentiscus and Quercus ilex saplings in severe drought and high temperature conditions. - Environ. Exp. Bot., 39: 213-220.

GORETA S., BUCEVIC-POPOVIC V., SELAK G.V., PAVELAVRANCIC M., PERICA S., 2008 - Vegetative growth, superoxide dismutase activity and ion concentration of salt stressed watermelon as influenced by rootstock. - J. 
Agr. Sci. 146: 695-704 .

HUANG Y., BIE Z.H., HE S., HUA B., ZHEN A., LIU Z.H., 2010 Improving cucumber tolerance to major nutrients induced salinity by grafting onto Cucurbita ficifolia. Environ. Exp. Bot., 69: 32-38.

IKEDA H., KAWASHIRO H., 2005 - The basis for vegetable production (in Japanese). - Nouwenkyo Press. Tokyo.

KHAH E.M., KAKAVA E., MAVROMATIS A., CHACHALIS D., GOULAS C., 2006 - Effect of grafting on growth and yield of tomato (Lycopersicon esculentum Mill.) in greenhouse and open-field. - J. Appl. Hort., 8: 3-7.

KOLEVA I., VAN BEEK T.A., LINSSEN J.P.H., DE GROOT A., EVSTATIEVA L.N., 2002 - Screening of plant extracts for antioxidant activity: a comparative study on three testing methods. - Phytochem. Anal., 13: 8-17.

KOZLOWSKI T.T., PALLARDY S.G., 1984 - Effects of flooding on water, carbohydrate and mineral relations, pp. 165193. In: KOZLOWSKI T.T. (ed.) Flooding and plant growth. Academic Press Inc., Orlando, Florida, USA, pp. 356.

KRUMBEIN A., SCHWARZ D., 2013 - Grafting: A possibility to enhance health-promoting and flavour compounds in tomato fruits of shaded plants? - Sci. Hortic., 149: 97-107.

KUMAR P., LUCINI L., ROUPHAEL Y., CARDARELLI M., KALUNKE R.M., COLLA G., 2015 a - Insight into the role of grafting and arbuscular mycorrhiza on cadmium stress tolerance in tomato. - Front. Plant Sci., 6: 477.

KUMAR P., ROUPHAEL Y., CARDARELLI M., COLLA G., 2017 - Vegetable grafting as a tool to improve drought resistance and water use efficiency. - Front. Plant Sci., 8: 1130.

KYRIACOU M.C., ROUPHAEL Y., COLLA G., ZRENNER R.M., SCHWARZ D., 2017 - Vegetable grafting: The implications of a growing agronomic imperative for vegetable fruit quality and nutritive value. - Front. Plant Sci., 8: 741.

LEE S.H., CHUNG G.C., STEUDLE E., 2007 - Low temperature and mechanical stresses differently gate aquaporins of root cortical cells of chilling-sensitive cucumber and resistant fig leaf gourd. - Plant Cell Environ., 28: 11911202.

LUTTS S., KINET J.M., BOUHARMONT J., 1995 - Changes in plant response to $\mathrm{NaCl}$ during development of rice varieties differing in salinity resistance. - J. Exp. Bot., 46: 1843-1852.

MARTNEZ-BALLESTA M.C., ALCARAZ-LPEZ C., MURIES B., MOTA-CADENAS C., CARVAJAL M., 2010 - Physiological aspects of rootstok-scion interactions. - Sci. Hort., 127: 112-118.

MASSAI R., REMORINI D., TATTINI M., 2004 - Gas exchange, water relations and osmotic adjustment in two scion/rootstock combinations of Prunus under various salinity concentrations. - Plant Soil, 259: 153-162.

MOYA J.L., TADEO F.R., GOMEZ-CADENAS A., PRIMOMILLO E., TALON M., 2002 - Transmissible salt tolerance traits identified through reciprocal grafts between sensitive Carrizo and tolerant Cleopatra citrus genotypes. - J. Plant Physiol., 159: 991-998.

PREGITZER K.S., KING J.S., 2005 - Effect of soil temperature on nutrient uptake, pp. 277-310. - In: RAD H.B. (ed.) Nutrient acquisition by plants: an ecological perspective. Springer-Verlag, Berlin, Heidelberg, Germany, pp. 348.

QIU-YAN Y., ZENG-QIANG D., JING-DONG M., XUN L.I., FEI D., 2013 - Low root zone temperature limits nutrient effects on cucumber seedling growth and induces adversity physiological response. - J. Int. Agric., 12(8): 1450-1460.

RAEISI M., BABAIE Z., PALASHI M., 2014 - Effect of chemical fertilizers and bio-stimulators containing amino acid on quality and quantitative and qualitative characteristics of tomato (Lycopersicum esculentum) var. Cal. - J. Int. J. BioSci., 4(1): 425-431.

RIVERO R.M., RUIZ J.M., SANCHES E., ROMERO L., 2003 Does grafting provide tomato plants an advantage against $\mathrm{H}_{2} \mathrm{O}_{2}$ production under conditions of thermal shock? - Physiol. Plant., 117: 40-50.

ROUPHAEL Y., CARDARELLI M., REA E., COLLA G., 2008 Grafting of cucumber as a means to minimize copper toxicity. - Environ. Exp. Bot., 63: 49-58.

ROUPHAEL Y., KYRIACOU M.C., COLLA G., 2018 - Vegetable grafting: A toolbox for securing yield stability under multiple stress conditions. - Front. Plant Sci., 8: 2255.

ROUPHAEL Y., REA E., CARDARELLI M., BITTERLICH M., SCHWARZ D., COLLA G., 2016 - Can adverse effects of acidity and aluminum toxicity be alleviated by appropriate rootstock selection in cucumber? - Front. Plant Sci., 7: 1283.

RUIZ J.M., BELAKBIR L., RAGALA J.M., ROMERO L., 1997 Response of plant yield and leaf pigments to saline conditions: effectiveness of different rootstocks in melon plants (Cucumis melo L). - Soil Sci. Plant Nutr., 43: 855862.

SALEHI R., KASHI A., LEE S.G., HOU Y.C., LEE J.M., BABALAR M., DELSHAD M., 2010 - Assessing the survival and growth performance of Iranian melons to grafting onto Cucurbita rootstocks. - Int. J. Hydrol. Sci. Technol., 27(1): 1-6.

SANTA-CRUZ A., MARTINEZ-RODRIGUEZ M.M., PEREZALFOCEA F., BOLARIN M.C., 2002 - The rootstock effect on the tomato salinity response depends on the shoot genotype. - Plant Sci., 165: 825-831.

SINGLETON V.L., ROSSI J.A., 1965 - Colorimetry of total phenolics with phosphomolybdic phosphotungstic acid reagents. - Am. J. Enol. Vitic., 16: 144-158.

TACHIBANA S., 1982 - Comparison of effects of root temperature on the growth and mineral nutrition of cucumber and fig leaf gourd. - J. Jpn. Soc. Hort. Sci., 51: 299308.

VAN DER PLOEG A., HEUVELINK E., 2005 - Influence of suboptimal temperature on tomato growth and yield: a review. - J. Hort. Sci. Biotechnol., 80: 652-659.

VENEMA J.H., DIJK B.E., BAX J.M., VAN HASSELT P.R., 
ELZENGA T.M., 2008 - Grafting tomato (Solanum lycopersicum) onto the rootstock of a high-altitude accession of Solanum habrochaites improves suboptimal-temperature tolerance. - Environ. Exp. Bot., 63: 359-367.

WILLITS D.H., PEET M.M., 1998 - The effect of night temperature on greenhouse grown tomato yields in warm climates. - Agric. For. Meteorol., 92: 191-202.

YAN Q., ZENG-QIANG D., JING-DONG M., XUN L., FEI D., 2013 - Low root zone temperature limits nutrient effects on cucumber seedling growth and induces adversity physiological response. - J. Integr. Agric., 12(8): 1450-1460.

YANG L.F., ZHU Y.L., HU C.M., LIU Z.L., WEI G.P., 2006 -
Effects of salt stress on biomass formation and ion partition in hydroponically cultured grafted cucumber. Acta. Bot. Boreal-Occident Sin., 26: 2500-2505. In Chinese with English summary.

ZHOU Y.H., HUANG L.F., ZHANG Y., SHI K., YU J.Q., NOGUES S., 2007 - Chill-induced decrease in capacity of $\mathrm{RuBP}$ carboxylation and associated $\mathrm{H}_{2} \mathrm{O}_{2}$ accumulation in cucumber leaves are alleviated by grafting onto fig leaf gourd. - Ann Bot., 100: 839-848.

ZHOU Y.H., WU J.X., ZHU L.J., SHI K., YU J.Q., 2009 - Effects of phosphorus and chilling under low irradiance on photosynthesis and growth of tomato plants. - Biol. Plant., 53: 378-382. 